\title{
A comparison between glass fiber and membrane filters for the estimation of phytoplankton POC and DOC production
}

\author{
Xosé A. G. Morán*, Josep M. Gasol, Laura Arin, Marta Estrada \\ Departament de Biologia Marina i Oceanografia, Institut de Ciències del Mar, CSIC, \\ Pg. Joan de Borbó, s/n, E-08039 Barcelona, Spain
}

\begin{abstract}
We tested the performance of 2 types of glass fiber filters (GF/F: $0.7 \mu \mathrm{m} ; \mathrm{GF} / \mathrm{C}: 1.2 \mu \mathrm{m}$ ) and 2 membrane filters (PC0.2: polycarbonate $0.2 \mu \mathrm{m}$; CE0.22: mixed cellulose esters $0.22 \mu \mathrm{m}$ ) in estimating chlorophyll $a$ and primary production with the ${ }^{14} \mathrm{C}$ technique. Four experiments were carried out with water samples from the NW Mediterranean, the NE Atlantic and the Antarctic Ocean. The first experiment compared measurements of particulate organic carbon (POC) production whereas the other 3 also considered total (TOC) and dissolved (DOC) carbon fixation. No significant differences among filters were found regarding chlorophyll a retention but large discrepancies existed in the amount of labelled organic carbon retained in all the experiments. Both types of glass fiber filters, especially GF/F, yielded higher values of apparent $\mathrm{PO}^{14} \mathrm{C}$ recovery than the membrane filters. The GF/Fderived POC production rates were up to twice the PC0.2-derived rates and $63 \%$ higher than CE0.22derived ones. Accordingly, the estimated rates of phytoplanktonic DOC production were higher with the membrane filters in comparison to the GF/F ones. This discrepancy was attributed to a high $\mathrm{DO}^{14} \mathrm{C}$ adsorption to the glass fibers of GF filters. Due to uncertainties in the magnitude of this process in other samples, we conclude that GF filters are not suitable when particulate primary production must be measured without interference of released dissolved products, and that membrane filters should be used instead.
\end{abstract}

KEY WORDS: Filter types · Phytoplankton $\cdot$ POC and DOC production · Chlorophyll $\cdot$ Cell abundance

\section{INTRODUCTION}

In marine ecology, vacuum filtration is a common step involved in a variety of techniques aimed at measuring biomass and production. For phytoplankton in particular, concentration of chlorophyll a (chl a) is commonly reported as a surrogate for biomass (Yentsch \& Mentzel 1963, Parsons et al. 1984). Since first proposed by Steeman-Nielsen (1952), the ${ }^{14} \mathrm{C}$ technique has been the most widely used method for estimating primary production. Other methods, such as measuring changes in $\mathrm{O}_{2}$ concentration with the automated Winkler technique (Williams \& Jenkinson 1982) or the stable isotope ${ }^{13} \mathrm{C}$ technique (Hama et al. 1983), need expen-

\footnotetext{
•E-mail: xelu@icm.csic.es
}

sive equipment or might have lower sensitivity when working in oligotrophic waters, which comprise more than $75 \%$ of the world's ocean surface. Prior to subsequent analyses, both chl $a$ and ${ }^{14} \mathrm{C}$-primary production measurements usually require the concentration of the phytoplanktonic cells on a filter of small pore size (mostly filters of sizes between 0.2 and $0.7 \mu \mathrm{m}$ ). Although there is quite an abundance of literature on the retention efficiencies of different filters concerning small-sized phytoplankters (e.g. Li \& Dickie 1985, Li 1990, Stockner et al. 1990, Lee et al. 1995, Gasol \& Morán 1999), the potential implications of filter characteristics for determinations of primary production still remain largely unexplored.

Filters may be made of diverse organic and inorganic materials. Those of glass fiber (GF), polycarbonate (PC) and mixed cellulose esters (CE) are the most fre- 
quently used. A bibliographical survey of 20 papers with data on ${ }^{14} \mathrm{C}$ primary production published during 1997 in 'Journal of Plankton Research', 'Limnology and Oceanography' and 'Marine Ecology Progress Series' indicated that, in practice, GF filters (mainly GF/F) are accepted as a standard for chl a determination $(89 \%$ of the studies). For primary production measurements GF filters are the most used too, being chosen in 9 papers $(40 \% \mathrm{GF} / \mathrm{F}$ and $5 \% \mathrm{GF} / \mathrm{C})$, while $\mathrm{PC}$ and $\mathrm{CE}(0.2$ or $0.45 \mu \mathrm{m}$ ) were used in only 3 papers each. Filtration was avoided and total organic carbon production was directly estimated in $25 \%$ of the papers, mainly in photosynthesis-irradiance experiments using the Photosynthetron described by Lewis \& Smith (1983). Overall, GF filters were used in $60 \%$ of the papers involving filtration. In general, the authors referred generically to 'primary production' results, although in a few papers an explicit mention of 'particulate primary production' was made. Filters of the above-mentioned types have been used for the purpose of separating particulate from dissolved (i.e. extracellular release of photosynthate) production, for instance GF/F in Witek et al. (1997), CE $0.45 \mu \mathrm{m}$ in Milligan \& Cosper (1997) and PC $0.2 \mu \mathrm{m}$ in Maurin et al. (1997). According to the surveyed literature, $\sim 0.2 \mu \mathrm{m}$ seems to be the most widely accepted pore size as operational cut-off for the dissolved fraction. Although it has been reported that the adsorption of dissolved organic carbon to GF filters could lead to incorrect results in particulate primary production experiments (Maske \& Garcia-Mendoza 1994), very few papers have addressed the possible discrepancies in the estimates of primary production due to the use of different filter types (e.g. Joint et al. 1993, Chavez et al. 1995). Recently Karl et al. (1998), using an extended temporal dataset, explicitly questioned the adequacy of using GF/F filters for the measurement of primary production.

We compared 4 small pore-sized filters, 2 glass fiber $(G F / F$ and $G F / C$ ) and 2 membrane (CE of $0.22 \mu \mathrm{m}$ pore size, $\mathrm{PC}$ of $0.2 \mu \mathrm{m}$ pore size) filters, extensively used in the literature. The effects of these and other filters on picoplanktonic abundance, community structure and bacterial activity were discussed in detail in Gasol \& Morán (1999). Here, we tested their performance in measuring both total biomass - as chl $a$ and as cell abundance - and the retention of newly synthesized organic carbon. This was done in water samples from 3 regions of very different ecological characteristics. Special attention was paid to the estimates of particulate versus dissolved primary production obtained with the different filters. For that reason, independent measurements of total organic carbon (TOC) production were made in order to check for biases due to filtration. To our knowledge, no comprehensive test with the 3 types of filters (GF, PC and CE) and in different areas has been made with this purpose before. As discussed further, the choice of membrane or GF filters has important consequences for the estimated parameters.

\section{MATERIAL AND METHODS}

Water samples and filters used. Four experiments (Table 1) were performed between 1997 and 1998 with water from 2 localities on the Catalan coast, NW Mediterranean (Expts 1 and 2); the Atlantic Ocean, offshore of the Ría de Vigo estuary in Galicia, NW Spain (Expt 3) and the Weddell Sea, Antarctica (Expt 4).

For Expts 1 and 2, samples of 1.51 of surface water were collected the day before, introduced in acidrinsed 21 Nalgene jars and left in a controlled-temperature chamber at in situ temperature $\left( \pm 1^{\circ} \mathrm{C}\right)$. For primary production measurements, 2 light and 1 dark aluminium foil covered jars were incubated under a 12:12 h light-dark cycle with irradiance being approximately $250 \mu \mathrm{mol} \mathrm{m} \mathrm{m}^{-2} \mathrm{~s}^{-1}$, close to the in situ value. Expts 3 and 4 were done on board RVs 'Cornide de Saavedra' and 'Hespérides' respectively, and started

Table 1. Location of the experiments, filters tested and the initial $(t=0)$ concentration of chlorophyli a (chl a) and heterotrophic bacteria in the water used for the experiments. The $c h 1$ a value given was measured on a GF/F filter. Filters - GF/F, GF/C: glass fiber; PC0.2: $0.2 \mathrm{~mm}$ pore size polycarbonate; CE0.22: $0.22 \mu \mathrm{m}$ pore size mixed cellulose esters

\begin{tabular}{|c|c|c|c|c|c|c|c|}
\hline Expt & Location & Filter types & Date & Position & $\begin{array}{l}\text { Temp. } \\
\left({ }^{\circ} \mathrm{C}\right)\end{array}$ & $\begin{array}{c}\mathrm{Chl} a \\
\left(\mathrm{mg} \mathrm{m}^{-3}\right)\end{array}$ & $\begin{array}{l}\text { Bacteria } \\
\text { (cells } \mathrm{ml}^{-1} \text { ) }\end{array}$ \\
\hline 1 & $\begin{array}{l}\text { Masnou, } \\
\text { NW Mediterranean }\end{array}$ & $\mathrm{GF} / \mathrm{F}, \mathrm{GF} / \mathrm{C}, \mathrm{PC} 0.2$ & $14 \operatorname{Jan} 1997$ & $41^{\circ} 28^{\prime} \mathrm{N}, 02^{\circ} 19^{\prime} \mathrm{E}$ & 1.4 & 2.84 & $2.9 \times 10^{5}$ \\
\hline 2 & $\begin{array}{l}\text { Blanes, } \\
\text { NW Mediterranean }\end{array}$ & GF/F, GF/C, PCo.2 & $13 \operatorname{Mar} 1997$ & $41^{\circ} 40^{\prime} \mathrm{N}, 02^{\circ} 47^{\prime} \mathrm{E}$ & 14 & 1.04 & $2.0 \times 10^{6}$ \\
\hline 3 & $\begin{array}{l}\text { Ría de Vigo, } \\
\text { NW Spain }\end{array}$ & GF/F, GF/C, PC0.2, CE 0.22 & 23 May 1997 & $42^{\circ} 09^{\prime} \mathrm{N}, 08^{\circ} 55^{\prime} \mathrm{W}$ & 17 & 0.42 & $5.9 \times 10^{5}$ \\
\hline 4 & $\begin{array}{l}\text { Weddell Sea, } \\
\text { Antarctica }\end{array}$ & $\mathrm{GF} / \mathrm{F}, \mathrm{CE} 0.22$ & 26 Jan 1998 & $60^{\circ} 19^{\prime} \mathrm{S}, 40^{\circ} 43^{\prime} \mathrm{W}$ & -1.4 & 0.62 & $1.6 \times 10^{5}$ \\
\hline
\end{tabular}


within an hour after water collection. Water was taken from the surface $(5 \mathrm{~m})$ in Expt 3 and from $40 \mathrm{~m}$ depth in Expt 4 with 121 Niskin bottles, and subsamples $(70 \mathrm{ml}$ ) were introduced in sterile polystyrene tissue culture bottles. Dark bottles were covered with aluminium foil. Expt 3 was performed under natural light conditions on deck with circulating surface water. Expt 4 was made in a controlled-temperature chamber in an incubator kept at in situ temperature under an irradiance of $50 \mu \mathrm{mol} \mathrm{m} \mathrm{m}^{-2} \mathrm{~s}^{-1}$.

The filters compared (see Table 1 for details) were inorganic GF (Whatman GF/F $0.7 \mu \mathrm{m}$ ) and organic, either PC (Millipore GTTP $0.2 \mu \mathrm{m}$, hereafter PC0.2) or mixed CE - acetate and nitrate-(Millipore GSWP $0.22 \mu \mathrm{m}$, hereafter CE0.22). Whatman GF/C $1.2 \mu \mathrm{m}$ filters were also assayed in 3 experiments, as effective pore sizes in GF filters are normally much smaller than nominally stated by the maker (Sheldon 1972), and they have been, and still are, used as an alternative to $\mathrm{GF} / \mathrm{F}$ in chl a or primary production measurements (e.g. Lindqvist \& Lignell 1997, Sciandra et al. 1997). All filters used were $25 \mathrm{~mm}$ in diameter. For all filtrations, pressure was kept below $80 \mathrm{~mm} \mathrm{Hg}$.

Chlorophyll a. In Expts 1 and 2, parallel 1.51 water samples were kept in 21 Nalgene jars in the same conditions that the ${ }^{14} \mathrm{C}$ inoculated bottles, and sampled at the same times for chl a determination. At the end of both experiments $(t=24 \mathrm{~h}), 2$ to 3 replicate measurements of chl a were made for each filter and the observed coefficient of variation was used for calculating SDs for the previous sampling times. In the other 2 experiments, chl a was measured once at the beginning of the experiment. Samples of 50 to $100 \mathrm{ml}$ were filtered and the filters frozen. In Expts 1 and 2, filters were ground in acetone $(90 \%)$ ) and left to extract for at least $2 \mathrm{~h}$ in the dark at room temperature. In Expts 3 and 4 pigments were extracted in acetone for $24 \mathrm{~h}$ in the dark at $4^{\circ} \mathrm{C}$ prior to fluorescence measurements. In all cases, the fluorescence of the chl a extracts was estimated with a Turner Designs fluorometer.

Algal and bacterial abundance. In Expts 1 and 2 samples of $100 \mathrm{ml}$ were taken at the beginning and the end of the incubation from the non-labelled Nalgene jars to determine the composition of the phytoplankton assemblages. In Expts 3 and $4100 \mathrm{ml}$ samples were taken simultaneously with the water for the incubations. The samples were fixed with formalin-hexamine $(0.4 \%$ final concentration) and counted by means of inverse microscopy following the Utermöhl (1958) technique.

Flow cytometric determination of algae and bacteria was performed at all sampling times in Expts 1 and 2 and with initial samples in the other 2 experiments, using a FACScalibur (Becton \& Dickinson) with a laser emitting at $488 \mathrm{~nm} .1 .2 \mathrm{ml}$ samples were fixed with a
$1 \%$ paraformaldehyde $+0.05 \%$ glutaraldehyde solution, frozen in liquid $\mathrm{N}_{2}$ and kept at $-80^{\circ} \mathrm{C}$. Total abundance and the effect of filtration was investigated for heterotrophic bacteria and 3 picoautotrophic groups (Synecchococcus, Prochlorococcus and picoeukaryotes) or 'ultraphytoplankton' as used by Li (1997). For further methodological details and results see Gasol \& Morán (1999)

Measurements of organic carbon production. The experimental jars and bottles were spiked with ${ }^{14} \mathrm{C}$ bicarbonate (VKI, Denmark): $68.8 \mu \mathrm{Ci}\left(2.55 \times 10^{6} \mathrm{~Bq}\right)$ in Expt $1 ; 66.5 \mu \mathrm{Ci}\left(2.46 \times 10^{6} \mathrm{~Bq}\right)$ in Expt $2 ; 10 \mu \mathrm{Ci}(3.70$ $\left.\times 10^{5} \mathrm{~Bq}\right)$ in Expt 3 and $7.88 \mu \mathrm{Ci}\left(2.91 \times 10^{5} \mathrm{~Bq}\right)$ in Expt 4. Time-zero samples were processed immediately at the beginning of each experiment. Thereafter, samples were taken at 4 to 5 time intervals to characterize the time-course of ${ }^{14} \mathrm{C}$ uptake in the particulate, dissolved and total organic fractions. At each sampling time, 2 light jars and 1 dark jar were sampled in Expts 1 and 2, and 2 clear and 2 dark bottles in Expts 3 and 4 .

In all experiments, subsamples $(60$ to $70 \mathrm{ml}$ ) were filtered onto the filters specified in Table 1 for determination of particulate primary production $\left(\mathrm{PO}^{14} \mathrm{C}\right)$. Filters placed into vials were exposed to concentrated $\mathrm{HCl}$ fumes for $12 \mathrm{~h}$ to remove inorganic ${ }^{14} \mathrm{C}$ before the addition of $4.5 \mathrm{ml}$ of liquid scintillation cocktail (Beckman Ready Safe or Packard Ultima Gold XR). Except in Expt 1, where only $\mathrm{PO}^{14} \mathrm{C}$ was measured, $5 \mathrm{ml}$ aliquots were taken from each jar or replicate bottle for determination of total $\left(\mathrm{TO}^{14} \mathrm{C}\right)$ and dissolved $\left(\mathrm{DO}^{14} \mathrm{C}\right)$ primary production. GF/F, PC0.2 and CE0.22 filters were used to separate the dissolved fraction. In the latter case, $5 \mathrm{ml}$ were gently filtered (by gravity or $<80 \mathrm{~mm}$ $\mathrm{Hg}$ vacuum pressure) and the filtrate collected in scintillation vials. $\mathrm{TO}^{14} \mathrm{C}$ and $\mathrm{DO}^{14} \mathrm{C}$ samples were acidified with $1 \mathrm{ml} \mathrm{HCl}(6 \mathrm{M}$ or $1 \mathrm{M}$ ) and either left open in an orbital shaker for 12 h or bubbled with air for approximately half an hour (Riemann \& Jensen 1991) for eliminating inorganic ${ }^{14} \mathrm{C}$. Subsequently, 10 to $17 \mathrm{ml}$ of scintillation cocktail was added to the vials.

Radioactivity was measured in a Beckman LS 6000LL liquid scintillation counter and disintegrations per minute $(\mathrm{dpm})$ were calculated with the external standard method. The time-zero $\mathrm{PO}^{14} \mathrm{C}$ values were substracted from subsequent samples for correction of non-photosynthetic incorporation. The mean dark bottle dpm's of $\mathrm{TO}^{14} \mathrm{C}$ and $\mathrm{DO}^{14} \mathrm{C}$ at each experiment (which were on average $49 \%$ of the light bottle dpm's) were also substracted from the light bottle ones. The radioactivity of the ${ }^{14} \mathrm{C}$-bicarbonate solution added to the incubation bottles was determined in $20 \mu \mathrm{l}$ aliquots

The carbon production rates were obtained after fitting the time-series data to simple compartmental carbon models. For Expt 1, where only PO14C was 
measured, we used a 2-compartment model: DIC (dissolved inorganic carbon) and POC, which accounted for the respiration of recently synthesized POC. In the rest of the experiments, a DOC compartment was also included, taking into account the possible removal of phytoplankton-released DOC by heterotrophic bacteria. For $\mathrm{TO}^{14} \mathrm{C}$ data a 2 -compartment model analogous to that of Expt 1 was used. Least-squares fitting was made with the SAAMII software (SAAM Institute, Washington). Data were weighed by the inverse of the standard deviation (SD) of replicates (Smith 1974). A $\mathrm{SD}$ of $10 \%$ of the value was used when replicates were absent, based on the average SD of previous experiments. The program provided fractional rates (in units $\mathrm{h}^{-1}$ ) of flux of $\mathrm{C}$ between compartments, which were in turn converted to carbon production rates using a concentration of DIC in the water of $25000 \mathrm{mg} \mathrm{C} \mathrm{m}^{-3}$ for the 4 experiments. The percent extracellular release (PER) was calculated as the ratio of the production rate of DOC to the sum of the production rates of POC and DOC. Further details of the compartmental models will be given elsewhere (Morán \& Estrada unpubl.). Statistical procedures other than time-course data fitting were made with Statistica software.

\section{RESULTS}

\section{Chlorophyll a}

Selected initial characteristics of the water samples are presented in Table 1 . The amount of chl a retained by the different filters is given in Table 2. The 3 filter types (GF/F, GF/C and PC0.2) showed no significant differences regarding chl a retention during Expts 1

Table 2. Average (SD) and coefficient of variation (CV) of chlorophyll a measurements after filtration through different filter types. Expt $1 \& 2$ : final $(t=24)$ values. Expt $3^{\circ}$ : test made in the Ría de Vigo at the same station as Expt 3 on 23 April, 1997. Expt 4: initial $(t=0)$ values

\begin{tabular}{|ccccc|}
\hline Expt & Filter type & $\begin{array}{c}\mathrm{Chl} a \\
\left(\mathrm{mg} \mathrm{m}^{-3}\right)\end{array}$ & $\begin{array}{c}\mathrm{CV} \\
(\%)\end{array}$ & $\mathrm{n}$ \\
\hline \multirow{2}{*}{1} & $\mathrm{GF} / \mathrm{F}$ & $5.00(0.22)$ & 8.9 & 3 \\
& $\mathrm{GF} / \mathrm{C}$ & $5.62(0.50)$ & 4.4 & 3 \\
& $\mathrm{PCO} .2$ & $5.77(0.49)$ & 8.5 & 3 \\
2 & $\mathrm{GF} / \mathrm{F}$ & $1.86(0.09)$ & 4.7 & 2 \\
& $\mathrm{GF} / \mathrm{C}$ & $1.82(0.11)$ & 6.1 & 2 \\
& $\mathrm{PCO} .2$ & $1.98(0.04)$ & 2.0 & 2 \\
3 & $\mathrm{GF} / \mathrm{F}$ & $1.18(0.18)$ & 15.4 & 2 \\
& $\mathrm{GF} / \mathrm{C}$ & $1.49(0.52)$ & 34.7 & 2 \\
& $\mathrm{CEO} 0.22$ & $1.06(0.04)$ & 4.0 & 2 \\
4 & $\mathrm{GF} / \mathrm{F}$ & $0.62(0.01)$ & 2.1 & 2 \\
& $\mathrm{CE} 0.22$ & $0.39(0.03)$ & 7.2 & 2 \\
\hline
\end{tabular}

and 2 (Fig. 1 and 2; 1 -way ANOVA, p = 0.14 and 0.30, respectively), despite the different initial content in chl $a$ of both experiments: $2.84 \mathrm{mg} \mathrm{m}^{-3}$ in Expt 1 and $1.04 \mathrm{mg} \mathrm{m}^{-3}$ in Expt 2. After an initial lag period of approximately $6 \mathrm{~h}$, in which chl a remained constant or slightly decreased, it increased during the rest of the light period and also in the dark for both experiments. At the beginning of the following day, values were close to double $\left(5.00 \mathrm{mg} \mathrm{m}^{-3}\right.$ in Expt 1 and $1.86 \mathrm{mg} \mathrm{m}^{-3}$ in Expt 2 as measured on $\mathrm{GF} / \mathrm{F})$. In the experiment done with Atlantic water (Expt $\left.3^{*}\right)$, no differences in chl a retention were found ( 1 -way ANOVA, $p=0.55$ ) while $\mathrm{GF} / \mathrm{F}$ filters retained significantly more chl a than CE0.22 in Expt 4 ( $t$-test, $p=0.008)$. The regressions between chl a estimates using $\mathrm{GF} / \mathrm{F}$ and $\mathrm{GF} / \mathrm{C}$ versus $\mathrm{PC} 0.2$ filters for all individual data available (Expts 1 and 2) were:

$$
\begin{gathered}
\text { chl } a_{\mathrm{GF} / F}=0.40+0.82 \mathrm{chl} a_{\mathrm{PCO} 2} \\
\mathrm{r}^{2}=0.92 ; \mathrm{p}=0.00004 ; \mathrm{n}=9 \\
\mathrm{chl} a_{\mathrm{GF} / \mathrm{C}}=0.13+0.97 \mathrm{chl} a_{\mathrm{PC} 0.2 ;} \\
\mathrm{r}^{2}=0.98 ; \mathrm{p}<0.000001 ; \mathrm{n}=9
\end{gathered}
$$

Intercepts were not significantly different from 0 , and the regression slopes were not significantly different from 1 ( $p=0.09$ and $p=0.61$, respectively).

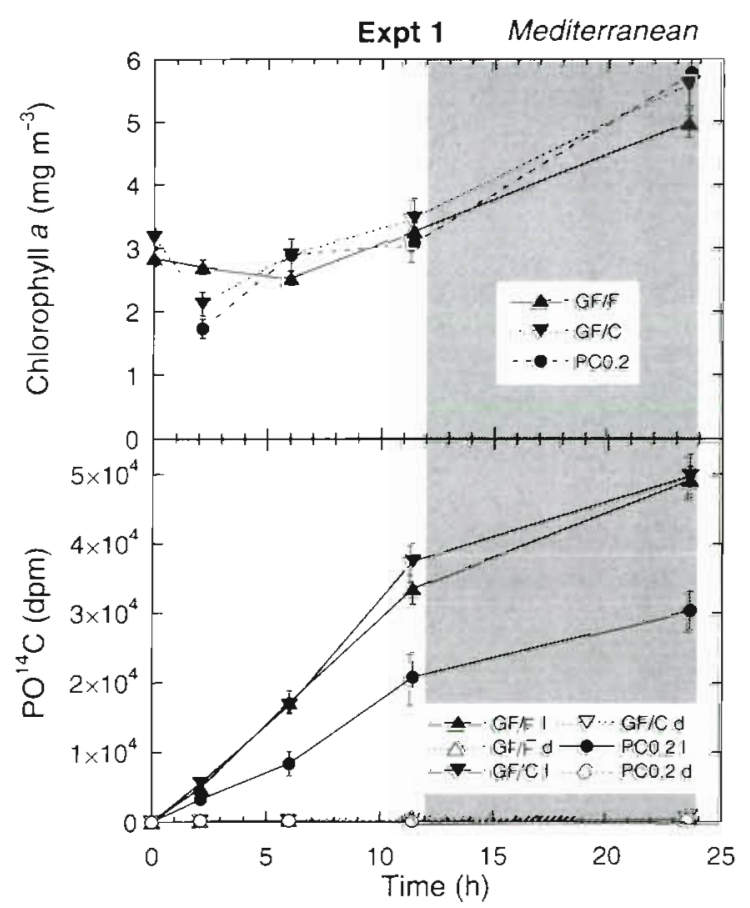

Fig. 1. Chlorophyll $a$ and $\mathrm{PO}^{14} \mathrm{C}$ dynamics in Expt 1. Data obtained after filtration with 3 filter types. Error bars are standard deviations of replicates. The shaded area represents the dark period. I: light bottle values. d: dark bottle values 


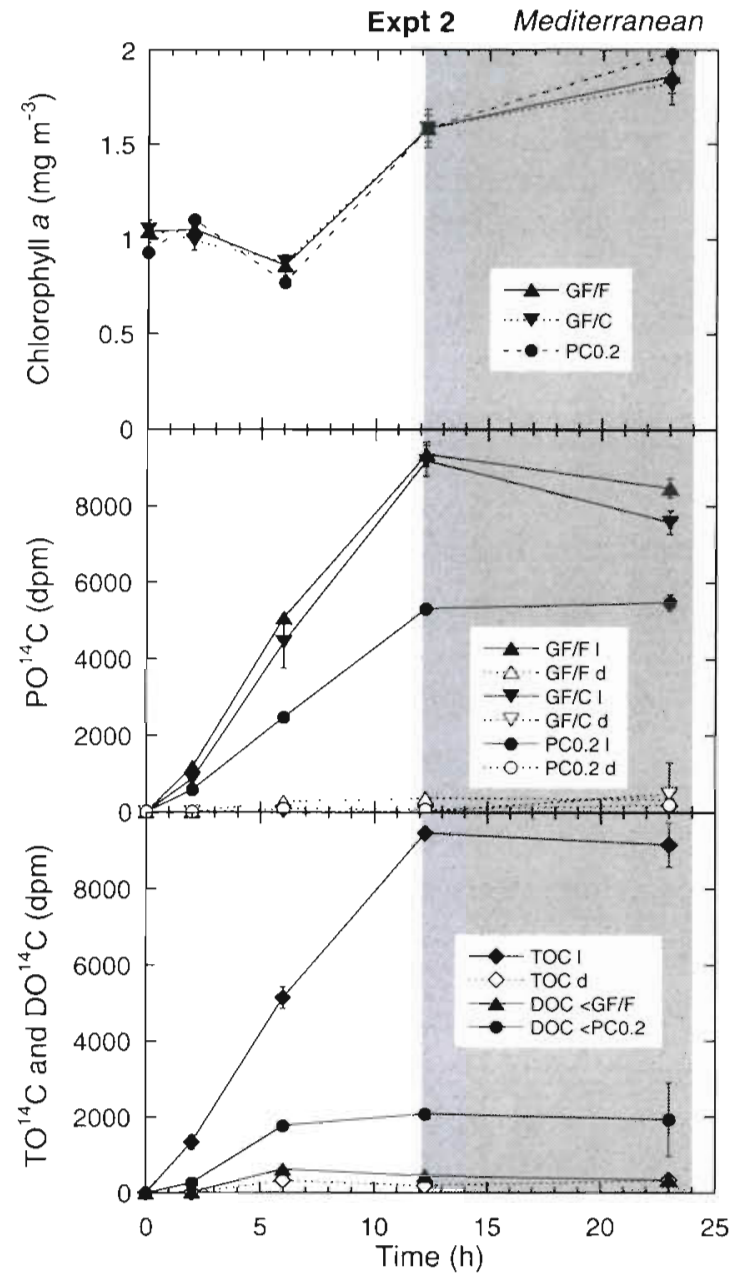

Fig. 2. Chlorophyll $a, \mathrm{PO}^{14} \mathrm{C}, \mathrm{DO}{ }^{14} \mathrm{C}$ and $\mathrm{TO}^{14} \mathrm{C}$ dynamics in Expt 2 obtained after filtration with 3 filter types. Error bars are standard deviations of replicates. DOC $<\mathrm{GF} / \mathrm{F}$ and DOC $<$ PC0.2 represents measured $\mathrm{DO}^{14} \mathrm{C}$ after filtration through GF/F and PC $0.2 \mu \mathrm{m}$ filters, respectively. Shaded area and $l, d$ as in Fig. 1

\section{Algal and bacterial abundance}

In the first 2 experiments diatoms were dominant,

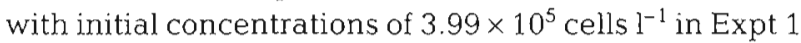
and $1.81 \times 10^{5}$ cells $1^{-1}$ in Expt 2 . The next most abundant groups were coccolithophorids in Expt $1(2.0 \times$ $10^{4}$ cells $\left.\mathrm{l}^{-1}\right)$ and flagellates in Expt $2\left(1.16 \times 10^{5}\right.$ cells $1^{-1}$ ). An increase in the abundance of almost all phytoplanktonic groups was observed at the end of the experiments in parallel to the increase in chl a. Thus, in Expt 1 diatoms reached $6.22 \times 10^{5}$ cells $1^{-1}$ and coccolithophorids $7.65 \times 10^{4}$ cells $^{-1}$. In Expt 2 the increase in diatom cell numbers was less marked, with a final abundance of $2.41 \times 10^{5}$ cells $\mathrm{l}^{-1}$. In Expt 3 , the most abundant group was small flagellates $\left(1.62 \times 10^{5}\right.$ cells $\left.\mathrm{l}^{-1}\right)$, followed by dinoflagellates $\left(4.46 \times 10^{4}\right.$ cells $\left.\mathrm{I}^{-1}\right)$
Table 3. Percentage of heterotrophic bacteria in the filtrates assessed by flow cytometry (SE of 5 replicates [Expt 1], 4 [Expt $3 \cdots$ ] or 2 [Expts $2 \& 3$ ]). Expt $3 \cdots$ : test made in the Ría de Vigo at the same station as Expt 3 , but 2 d before. -: not determined

\begin{tabular}{|c|c|c|c|c|c|}
\hline Treatment & 1 & 2 & 3 & $3 \cdots$ & 4 \\
\hline Unfiltered & 100 & 100 & 100 & 100 & 100 \\
\hline$<\mathrm{GF} / \mathrm{C}$ & $52.0(3.8)$ & $44.5(5.7)$ & $89.9(10.2)$ & $79.9(2.8)$ & - \\
\hline$<\mathrm{GF} / \mathrm{F}$ & $10.3(1.4)$ & $6.5(1.8)$ & - & $22.9(0.8)$ & 25.6 \\
\hline$<$ CE0.22 & - & - & - & $0.7(0.1)$ & 4.1 \\
\hline$<\mathrm{PC} 0.2$ & $2.7(0.5)$ & $4.6(1.6)$ & - & $2.2(0.2)$ & - \\
\hline
\end{tabular}

while diatoms were only $1.25 \times 10^{4}$ cells $\mathrm{l}^{-1}$. Similarly, flagellates dominated in Expt $4\left(2.66 \times 10^{5}\right.$ cells $\left.^{-1}\right)$, with dinoflagellate and diatom abundances of $3.14 \times$

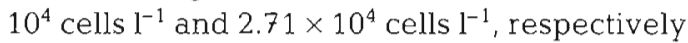

The percentage of picoautotrophs and heterotrophic bacteria passing the filters was dependent on the filter type (Table 3 for heterotrophic bacteria). In the Mediterranean experiments only Synechococcus and low numbers of picoeukaryotes were detected by flow cytometry. GF/C filters let through the highest percentage of both planktonic groups: as much as $90 \%$ and a minimum of $45 \%$ of the heterotrophic bacteria, but less than $15 \%$ of the 3 picoautotrophic groups considered (Synechococcus, Prochlorococcus and picoeukaryotes). GF/F filters also let through an appreciable amount of bacteria (from $7 \%$ to $26 \%$ of the total), but phytoplanktonic cells were effectively retained. The amount of heterotrophic bacteria and autotrophic cells passing through $\mathrm{PC} 0.2$ and $\mathrm{CE} 0.22$ was below $5 \%$.

\section{Measurements of organic carbon production}

Contrary to the chl a estimates, the amount of labelled organic carbon retained on the filter was clearly different with GF or with membrane filters (Figs. 1 to 4). In all cases, albeit to a different extent, estimates of $\mathrm{PO}^{14} \mathrm{C}$ on $\mathrm{GF} / \mathrm{F}$ or $\mathrm{GF} / \mathrm{C}$ were higher than on the corresponding membrane filter, either $\mathrm{PC}$ or CE. Table 4 shows the average ratios of GF estimates to membrane filter estimates for each experiment. Apparent $\mathrm{PO}^{14} \mathrm{C}$ retained by $\mathrm{PC} 0.2$ filters was 40 to $45 \%$ less than that retained by GF/F in the Mediterranean experiments. This difference was lower in the Atlantic and the Antarctic experiments, but still $17 \%$ (Expt 3) and 22\% (Expt 4) less organic carbon was retained on CE0.22 filters as compared to GF/F ones. When compared with directly measured $\mathrm{TO}^{14} \mathrm{C}$ data, in all experiments, GF/F estimates of $\mathrm{PO}^{14} \mathrm{C}$ (and also $\mathrm{GF} / \mathrm{C}$ estimates in Expt 2) were much closer to $\mathrm{TO}^{14} \mathrm{C}$ than PC0.2 ones (Figs. 2 to 4 ). 
Table 4. Comparison between the incorporation of ${ }^{14} \mathrm{C}$ (apparent $\mathrm{PO}^{14} \mathrm{C}$ ) with different filter types. At each time, the estimate with one filter was divided by the value with another filter and all the time-course data for the experiment were averaged (SD). - not determined

\begin{tabular}{|c|c|c|c|c|c|c|c|c|}
\hline Expt & & 1 & & 2 & & 3 & & 4 \\
\hline \multicolumn{9}{|l|}{ GF filters } \\
\hline $\mathrm{GF} / \mathrm{C} \div \mathrm{GF} / \mathrm{F}$ & 1.06 & $(0.08)$ & 0.87 & $(0.10)$ & 0.84 & $(0.14)$ & & - \\
\hline \multicolumn{9}{|l|}{ GF filters to $P C$} \\
\hline $\mathrm{GF} / \mathrm{F} \div \mathrm{PC} 0.2$ & 1.69 & $(0.24)$ & 1.85 & $(0.24)$ & & - & & - \\
\hline $\mathrm{GF} / \mathrm{C} \div \mathrm{PCO} 2$ & 1.78 & $(0.15)$ & 1.60 & $(0.19)$ & & - & & - \\
\hline \multicolumn{9}{|l|}{ GF filters to $\mathrm{CE}$} \\
\hline $\mathrm{GF} / \mathrm{F} \div \mathrm{CE} 0.22$ & & - & & - & 1.21 & $(0.30)$ & 1.28 & $(0.07)$ \\
\hline $\mathrm{GF} / \mathrm{C} \div \mathrm{CE} 0.22$ & & - & & - & 0.99 & $(0.13)$ & & - \\
\hline \multicolumn{9}{|c|}{ Each filter to $\mathrm{TO}^{14} \mathrm{C}$} \\
\hline $\mathrm{GF} / \mathrm{F} \div \mathrm{TO} \mathrm{O}^{14} \mathrm{C}$ & & - & 0.95 & $(0.05)$ & 0.91 & $(0.05)$ & 0.94 & $(0.02)$ \\
\hline $\mathrm{GF} / \mathrm{C} \div \mathrm{TO}^{14} \mathrm{C}$ & & - & 0.83 & $(0.13)$ & 0.81 & $(0.17)$ & & - \\
\hline $\mathrm{PC} 0.2 \div \mathrm{TO}^{14} \mathrm{C}$ & & - & 0.52 & $(0.07)$ & & - & & - \\
\hline $\mathrm{CE} 0.22 \div \mathrm{TO}^{14} \mathrm{C}$ & & - & & - & 0.79 & $(0.27)$ & 0.73 & $(0.05)$ \\
\hline
\end{tabular}

with the highest difference found in Expt 2 (29\% with PC0.2 and $6 \%$ with GF/F). Expt 3 and 4 yielded almost the same value of PER (19\% and $18 \%$, respectively, with CE0.22). With GF/F filters, PER was below $11 \%$ in all experiments.

\section{DISCUSSION}

Although filtration has been routinely used since the beginning of studies in plankton ecology, it is far from being a simple process (Brock 1983) and some of its associated problems have not yet been overcome (e.g. Hilmer \& Bate 1989). Apart from incomplete removal of cells and changes in community structure of several picoplankton groups (Gasol \& Morán 1999), the data presented here confirm serious

When the time course of $\mathrm{PO}^{14} \mathrm{C}$ during the $24 \mathrm{~h}$ was considered, in Expt 1 the amount of $\mathrm{PO}^{14} \mathrm{C}$ recovered on the 3 filters increased during the whole incubation, with a slower rate in the dark, in parallel to the increase in chl a (Fig, 1). On the contrary, in Expt 2, the increase in chl a observed after the dark period was not concomitant with an increase in labelled organic carbon which remained constant or decreased slightly (Fig. 2), presumably due to phytoplankton respiration.

The rates of organic $C$ production obtained with the different filters using the compartmental models are shown in Table 5. As expected, the rate of particulate primary production (POC-pr) obtained with GF/F filters was considerably higher than that obtained with $\mathrm{PC} 0.2$ filters (68\% higher in Expt 1 and $101 \%$ in Expt 2). For Expts 3 and 4, GF/F estimates were $29 \%$ and $37 \%$ higher respectively than CE0.22 estimates. in the Mediterranean experiments, POCpr obtained with GF/C filters was also higher than PC0.2 estimates. For the $\mathrm{GF} / \mathrm{F}$ filters, the rates of of total primary production (TOC-pr) were not significantly different from POC-pr estimates, whereas TOC-pr was always higher than POC-pr estimates for the membrane filters (Table 5). The estimates of phytoplanktonically produced DOC were in turn quite different depending on the filter used for separating the particulate and dissolved fractions (Fig. 5). Higher values of percent extracellular release (PER) were always obtained with membrane filters,
Table 5. Comparison of the POC, DOC and TOC production rates (SD) obtained after fitting time-course data obtained. with the different filter types. Units in $\mathrm{mg} \mathrm{C} \mathrm{m} \mathrm{C}^{-3} \mathrm{~h}^{-1}$-: not determined; pr: production rate

\begin{tabular}{|c|c|c|c|c|c|c|c|}
\hline Expt & 1. & & 2 & & 3 & & 4 \\
\hline \multicolumn{8}{|l|}{ POC-pr } \\
\hline $\mathrm{GF} / \mathrm{F}$ & $.34(0.75)$ & 3.06 & $(0.22)$ & 2.66 & $(0.21)$ & 0.37 & $(0.01)$ \\
\hline $\mathrm{GF} / \mathrm{C}$ & $.41(0.37)$ & 2.61 & $(0.49)$ & 2.03 & $(0.02)$ & & - \\
\hline $\mathrm{PC} 0.2$ & $.54(0.43)$ & 1.52 & $(0.14)$ & & - & & - \\
\hline $\mathrm{CE} 0.22$ & - & & - & 2.07 & $(0.14)$ & 0.27 & $(0.01)$ \\
\hline \multicolumn{8}{|l|}{ DOC-pr } \\
\hline $\mathrm{GF} / \mathrm{F}$ & - & 0.18 & $(0.06)$ & 0.31 & $(0.02)$ & 0.05 & $(0.01)$ \\
\hline $\mathrm{PC} 0.2$ & - & 0.62 & $(0.14)$ & 0.37 & $(0.05)$ & & - \\
\hline CE0.22 & - & & - & 0.49 & $(0.17)$ & 0.06 & $(0.02)$ \\
\hline \multicolumn{8}{|l|}{ TOC-pr } \\
\hline directly & - & 3.11 & $(0.18)$ & 2.74 & $(0.23)$ & 0.40 & $(0.02)$ \\
\hline GF/F (POC-pr + DOC-pr) & - & 3.24 & $(0.22)$ & 2.97 & $(0.21)$ & 0.42 & $(0.01)$ \\
\hline PC0.2 (POC-pr + DOC-pr) & - & 2.15 & $(0.20)$ & & - & & - \\
\hline CE0.22 (POC-pr + DOC-pr & r) - & & - & 2.56 & $\{0.22\}$ & 0.33 & $(0.02)$ \\
\hline
\end{tabular}




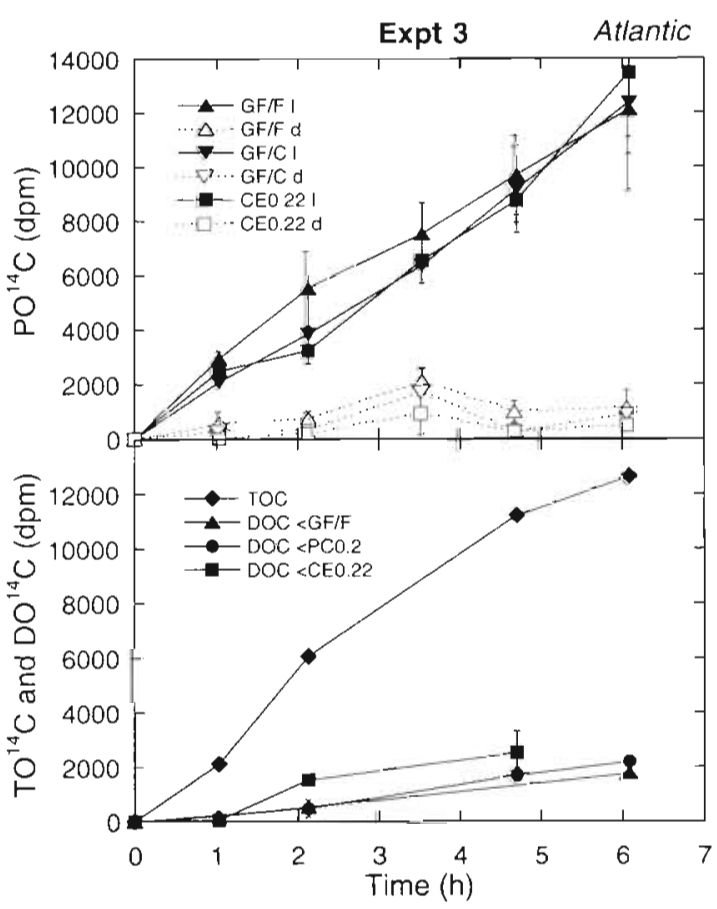

Fig. 3. $\mathrm{PO}^{14} \mathrm{C}, \mathrm{DO}^{14} \mathrm{C}$ and $\mathrm{TO}^{14} \mathrm{C}$ dynamics of Expt 3 with 4 filter types. Error bars are standard deviations of replicates. DOC $<C E 0.22$ represents measured $\mathrm{DO}^{14} \mathrm{C}$ after filtration through CE $0.22 \mu \mathrm{m}$ filters. Remaining code names as in Figs. $1 \& 2$

significant. The result could have been different if picoplankton had contributed a large fraction of total chl $a$ in the samples. Given the relatively high initial values of chl $a$ in all experiments $\left(>0.4 \mathrm{mg} \mathrm{m}^{-3}\right)$ and the results of the flow cytometry analyses, it may be safely assumed that most phytoplanktonic cells were larger than $\sim 1 \mu \mathrm{m}$ in diameter. Thus, it is not surprising that the results presented here do not agree with those of Venrick et al. (1987), who observed for 2 areas at $47^{\circ} \mathrm{N}$ and $24^{\circ} \mathrm{N}$ that on average, $4.3 \%$ and $8.9 \%$ respectively of total chl a (as retained by CE $0.45 \mu \mathrm{m}$ filters) was lost after passage through $\mathrm{GF} / \mathrm{C}$ filters. Most of their data corresponded to sites with chl a below $0.5 \mathrm{mg} \mathrm{m}^{-3}$ and were collected in open ocean waters, with a supposedly higher contribution of picoplankters.

Due to their larger nominal pore sizes, both GF/F and $\mathrm{GF} / \mathrm{C}$ filters were expected to let through a higher percentage of bacteria and ultraphytoplankton than PC0.2 or CE0.22 filters. This was so in the case of GF/C filters, but for GF/F filters it applied only to bacteria, whereas they performed better than any other filter type at retaining small phytoplankton (Expt $3 \cdot$, Table 3; see also Table 3 in Gasol \& Morán 1999). The difference in pore sizes between GF/C and GF/F filters was reflected in their relative retention efficiencies of heterotrophic bacteria (Table 3; Nagata 1986). These results could be related to the different architecture of

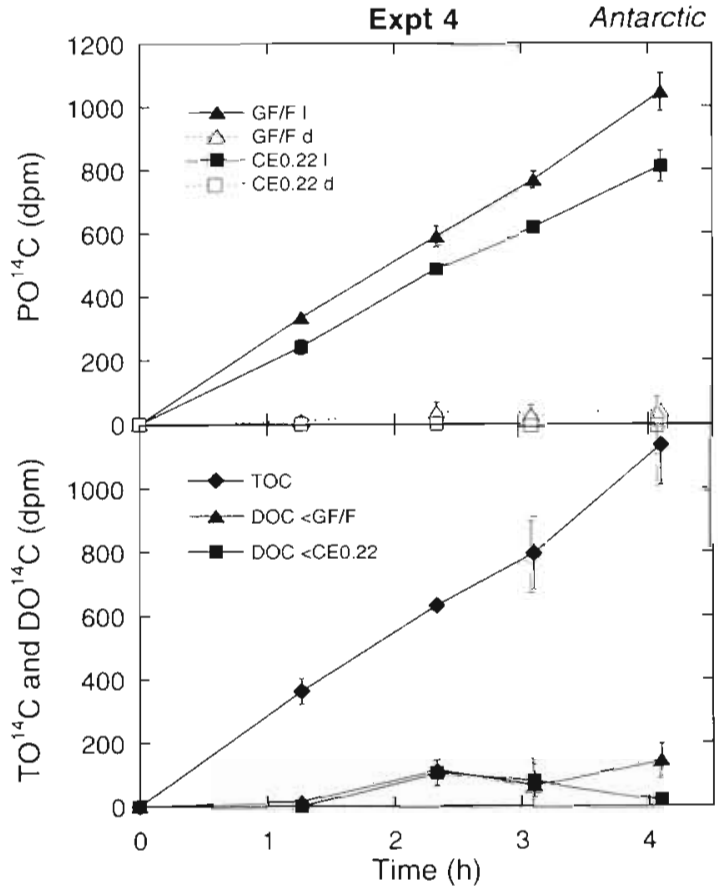

Fig. 4. $\mathrm{PO}^{14} \mathrm{C}, \mathrm{DO}^{14} \mathrm{C}$ and $\mathrm{TO}^{14} \mathrm{C}$ dynamics of Expt 4 with 2 filter types. Error bars are standard deviations of replicates. Code names as in previous figures

the filters. GF (and to a lesser extent CE) filters represent a trap-like matrix which effectively retains cells of a smaller diameter than that stated by the manufacturer. Furthermore, in PC filters, despite having 'real' pores of the stated size, the presence of some much larger holes may let through cells of considerably higher size (Stockner et al. 1990). In any case, the different retention efficiencies of ultraphytoplankton in our experiments were too small to be detected as concomitant changes in chl a retention.

\section{Measurements of organic carbon production}

The data presented here clearly show that GF filters may give much higher values of apparent particulate organic carbon production than membrane filters (Tables $4 \& 5$ ), contrary to the expectation derived from their relative pore sizes. In the Mediterranean experiments, the apparent POC-pr was on average $85 \%$ higher with GF/F than with PC0.2 filters. Higher apparent POC-pr also held for GF/C filters $(71 \%$ more than PC0.2). This overestimation of the POC-pr when GF filters were used is in agreement with the results obtained by Karl et al. (1998) at the ALOHA station, an oligotrophic site in the North Pacific, although the discrepancy shown here is considerably higher. These 


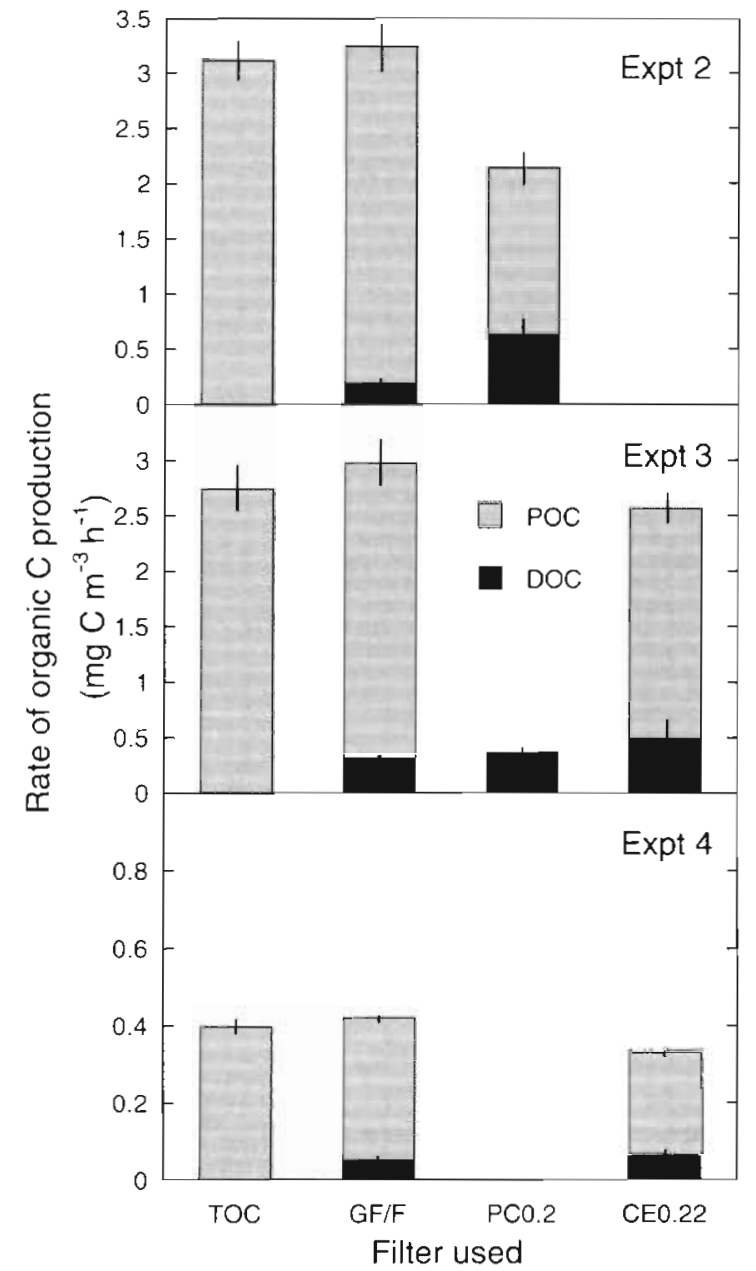

Fig. 5. TOC, POC and DOC production rates obtained with different filters after fitting time-course data in Expts 2, 3 and 4. Error bars are standard deviations of the estimates. Notice the different scale for Expt 4. Filter code names explained in the text

authors recovered on average $44 \%$ more ${ }^{14} \mathrm{C}$ activity onto GF/F filters than onto PC0.2 ones $130 \%$ if watercolumn integrated primary production estimates are compared). Significantly higher values of apparent POC-pr (on average $33 \%$ higher) were also found with GF/F filters when compared to CE0.22 ones.

We showed that there was not a substantial loss of phytoplanktonic cells, measured both as chl a (Table 2) or ultraphytoplankton abundances, after filtration through the assayed membrane filters. If we assume that the exposure to $\mathrm{HCl}$ fumes for eliminating $\mathrm{DI}^{14} \mathrm{C}$ worked equally for the different filter types, as both independent $\mathrm{TO}^{14} \mathrm{C}$ measurements and equivalent amounts of residual non-photosynthetic ${ }^{14} \mathrm{C}$ retained on all the filters from the dark bottles seemed to confirm, the most likely explanation for the higher apparent $\mathrm{PO}{ }^{14} \mathrm{C}$ on $\mathrm{GF}$ filters is the retention of labelled dis- solved organic carbon. An alternative possibility, a higher retention on GF/F filters of bacterial PO ${ }^{14} \mathrm{C}$ after uptake of $\mathrm{DO}^{14} \mathrm{C}$ during the experiments, was discarded because GF/F filters let through more bacterial cells than the 2 membrane filters assayed (Table 3 ). Furthermore, the possible return during the incubations of $\mathrm{DO}^{14} \mathrm{C}$ to the particulate pool by the fraction of bacteria passing GF filters but being retained onto membrane ones was surely of very low importance. Had it been noticeable, this higher retention of bacterial $\mathrm{PO}^{14} \mathrm{C}$ on membrane filters could have counteracted the adsorption of $\mathrm{DO}^{14} \mathrm{C}$ to $\mathrm{GF}$ ones, hence decreasing the discrepancy between organic ${ }^{14} \mathrm{C}$ measurements in both filter types. Bacteria passing GF/F filters are mostly small-sized bacteria (Gasol \& Morán 1999), therefore with a comparatively much lower biomass contribution, and are probably inactive (Bird \& Kalff 1993, Gasol et al. 1995).

The adsorption of $D \mathrm{O}^{14} \mathrm{C}$ to $\mathrm{GF} / \mathrm{F}$ and $\mathrm{GF} / \mathrm{C}$ filters was first observed by Maske \& Garcia-Mendoza (1994), although it is likely that this phenomenon was behind the losses of ${ }^{14} \mathrm{C}$ activity recovered onto PC filters when compared to GF measurements reported by Goldman \& Dennettt (1985), Lignell (1992) or Joint et al. (1993). Since the publication of Maske \& GarciaMendoza's paper, little consideration has been given to their warning against the use of GF filters, and Chavez et al. (1995) were among the few researchers to specifically address that subject. These authors showed a single primary production profile at the ALOHA station in which PC0.2 and GF/F estimates were essentially the same. More recently, Karl et al. (1998) used data from the same station to show that adsorption of DOC to GF/F filters was the most likely cause of overestimation of POC-pr with that filter type. In the present paper, we present further evidence that DOC adsorption to GF filters appears to apply to very different hydrographical and ecological conditions. The results of Karl et al. (1998) would thus be not only general, but could be in the lower part of the range of overestimation of 'true' POC production rates by using $\mathrm{GF} / \mathrm{F}$ filters.

As expected from a higher adsorption of $\mathrm{DO}^{14} \mathrm{C}$ to glass than to organic materials (Maske \& Garcia-Mendoza 1994) DOC-pr was in absolute and relative terms lower with GF/F filters (Table 5); thus, we regard the values obtained with membrane filters as more reliable. PER was below $30 \%$ in the 3 areas, in agreement with previously published values (e.g. Mague et al. 1980, Baines \& Pace 1991). The direct estimation of TO ${ }^{14} \mathrm{C}$ in Expts 2 to 4 allowed for an independent control of total primary production prior to its separation into particulate and dissolved. In Expt 3, the sum of the dissolved and particulate production using both filters was rather similar (Fig. 5). In Expts 2 and 4, the sum of 
$\mathrm{DOC}$ and POC production rates obtained with $\mathrm{PC} 0.2$ and CE0.22 filters, respectively, was lower than TOCpr (Fig. 5, Tables 4 \& 5), so the question of the 'true' DOC release remained unsolved. Unaccounted losses of label (relative to direct TOC measurements) have sometimes been reported when using PC (Goldman \& Dennett 1985) and CE filters (Gächter at al. 1984, Lignell 1990, 1992). Some possible explanations were suggested by Lignell (1992).

The variable differences found in apparent $\mathrm{PO}^{14} \mathrm{C}$ retention with $\mathrm{GF} / \mathrm{F}$ filters relative to membrane ones, which would range from a $6 \%$ excess (Maske \& Garcia-Mendoza 1994) to double the POC-pr (Expt 2, this paper), would depend on many factors, like the filter type (CE or PC) and pore size, the actual DOC release rate or the relative polarity of the dissolved molecules and the fibers. Here, the highest differences between membrane and $\mathrm{GF} / \mathrm{F}$ filter estimates of $\mathrm{PO}^{14} \mathrm{C}$ were observed in the Mediterranean experiments which, because of being performed in winter and with coastal water, presented the highest chl $a$ and primary production rates. Fig. 6 shows the relationships between GF/F and PC0.2 retention of chl a and organic ${ }^{14} \mathrm{C}$ with pooled data from Expts 1 and 2. Notice a slope not significantly different from 1 for chl a retention versus a significantly higher than 1 slope for organic ${ }^{14} \mathrm{C}$ retention. Two possible explanations for this high difference in apparent $\mathrm{PO}^{14} \mathrm{C}$ could be high $\mathrm{PER}$ and/or high affinity of released compounds to GF filters in these experiments. It could be speculated that this fact is related to the phytoplankton composition. Whereas in the other 2 experiments small flagellates prevailed, Expts 1 and 2 showed a marked dominance of diatoms, which reached $10^{5}$ cells $\mathrm{m} \mathrm{l}^{-1}$. High DOC release rates have been reported for diatoms in natural samples under P stress (Myklestad 1977) or in cultures: e.g. Biddanda \& Benner (1997) obtained a value of $32 \%$ PER for a Skeletonema costatum culture growing actively, even though GF/F filters were used. High lysis rates of growing phytoplankton assemblages were recently reported for the same Mediterranean region (Agusti et al. 1998). The winter coastal Mediterranean waters represented in any case a different environment when compared to the North Pacific waters sampled by Karl et al. (1998), where Prochlorococcus were responsible for more than $75 \%$ of total primary production. The differential phytoplankton composition of the Pacific and the Mediterranean samples could help explain the higher discrepancies found here. Yet another possible explanation for the higher difference in apparent $\mathrm{PO}^{14} \mathrm{C}$ retention (relative to $\mathrm{GF} / \mathrm{F}$ filters) given by PC0.2 filters when compared to CE filters could be a different inherent performance of $\mathrm{PC}$ and $\mathrm{CE}$ filter types, perhaps related to the 'matrix-like' structure of $\mathrm{CE}$ versus the track-etched structure of PC filters.
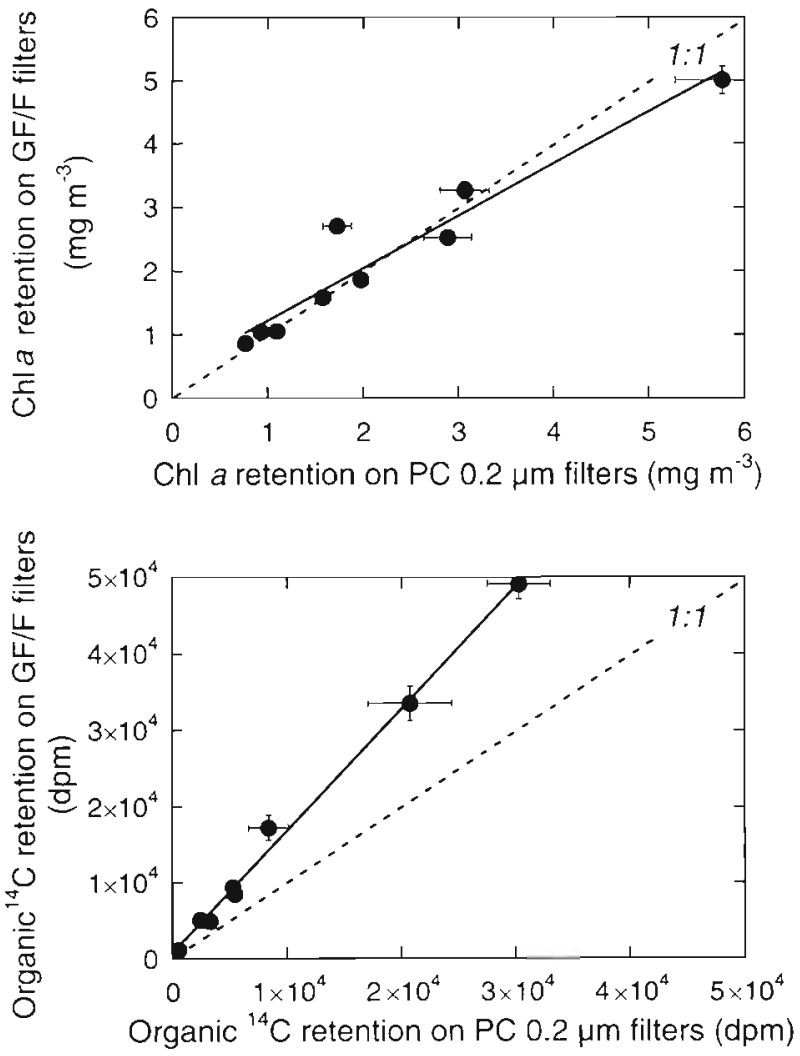

Fig. 6. Relationships between the chl a and organic ${ }^{14} \mathrm{C}$ retained by $G F / F$ and PC $0.2 \mu \mathrm{m}$ filters with pooled data from the Mediterranean (Expts 1 and 2). Error bars are standard deviations of replicates. Dashed lines represent the 1:1 relationship and solid lines are linear regressions. chl a data regression: $\operatorname{chl} a_{\mathrm{GF} / \mathrm{F}}=0.40+0.82 \mathrm{chl} \mathrm{apco}_{2} ; \mathrm{r}^{2}=0.92 ; \mathrm{p}=0.00004 ; \mathrm{n}=$ 9. Intercept not significantly different from 0 . Slope not significantly different from 1 . Organic ${ }^{14} \mathrm{C}$ data regression is: Org. ${ }^{14} \mathrm{C}_{\mathrm{GF} / \mathrm{F}}=763+1.60$ Org. ${ }^{14} \mathrm{C}_{\mathrm{PC0} 2.2} \cdot \mathrm{r}^{2}=0.99 ; \mathrm{p}<0.00001 ; \mathrm{n}=8$. Intercept not significantly different from 0 . Regression slope significantly different from 1 ( $p<0.0001)$

Grande et al. (1989) reported that primary production estimates obtained with CE $0.45 \mu \mathrm{m}$ filters were also $25 \%$ lower than PC $0.2 \mu \mathrm{m}$ ones and Karl et al. (1998) suggested that $C E$ and GF filters behaved similarly with regard to $\mathrm{DO}^{14} \mathrm{C}$ adsorption. We could directly compare estimates of $\mathrm{DO}^{14} \mathrm{C}$ with $\mathrm{CE} 0.22$ and $\mathrm{PC} 0.2$ filters only in Expt 3, with CE0.22 being higher than PC0.2 (Table 5, Fig. 5). Nevertheless, the still noticeable difference between CE0.22- and GF/F-derived POC production rates in Expts 3 and 4 would not support the hypothesis of an essentially similar $\mathrm{DO}^{14} \mathrm{C}$ adsorption to CE and GF filters as suggested by Karl et al. (1998), although the adsorption to CE filters could also depend on the dissolved compounds spectrum. Adsorption of dissolved compounds onto CE $0.45 \mu \mathrm{m}$ filters was reported (Nalewajko \& Lean 1972, Jayakumar \& Barnes 1983), but it seems to be of considerably 
lower importance when compared to the adsorption onto GF/F filters. Maske \& Garcia-Mendoza (1994) reported a relative adsorption capacity of 100 for GF/F filters, 21 for CE $0.45 \mu \mathrm{m}$ and 1 for PC 0.2

\section{Implications}

GF filters appear to be adequate for chl a determinations with the precaution that GF/F filters would be a safer choice instead of GF/C ones when working in low biomass waters in order to avoid losses of small phytoplankters (Yentsch 1983, Gasol \& Morán 1999). The best choice for the measurement of primary production with the ${ }^{14} \mathrm{C}$ technique would be to avoid filtration. Hence and strictly, only the report of TOC production rates (Schindler et al. 1972) could be recommended, but for practical reasons filtration and filter collection is still favoured. In oligotrophic sites, the measurement of TOC production may become an unachievable task given the usually higher variances found in direct TOC measurements, due to the necessarily small volumes (usually not more than $5 \mathrm{ml}$ ) imposed by liquid scintillation procedures. Furthermore, filtration is obviously necessary if we are interested in partitioning the primary production into dissolved and particulate.

Among the advantages explaining the present prevalence of GF/F filters are their low cost, high flow rate, high particle loading capacity and their compatibility with other ancillary measurements due to their physico-chemical stability (Karl et al. 1998). However, our results clearly showed for 3 very different areas that GF filters may greatly overestimate particulate primary production because of adsorption of dissolved compounds released contemporaneously with the incubation. Because of the unawareness of the exact amount of $\mathrm{DO}{ }^{14} \mathrm{C}$ being adsorbed, we would not recommend the use of $G F / F$ filters in routine particulate primary production determinations. In fact, the ${ }^{14} \mathrm{C}$ activity recovered onto them may be closer to an estimate of $\mathrm{TO}^{14} \mathrm{C}$ than of $\mathrm{PO}^{14} \mathrm{C}$. In our experiments we recovered an average of $93 \%$ of the total organic carbon produced onto GF/F filters. In a more oligotrophic area, a mean $85 \%$ of the TOC produced by phytoplankton was retained by GF/F filters (Table 5 in Karl et al. 1998).

We conclude that in primary production experiments with the ${ }^{14} \mathrm{C}$ technique, membrane filters (either PC0.2 or CE0.22) should be used instead of GF ones if fractionation into particulate and dissolved is required. The potential errors associated with separating both phases of organic carbon with $\mathrm{GF} / \mathrm{F}$ filters can also affect other determinations such as those of POC and DOC pools in the water. In this case, precombusting GF filters could increase the number of high polarity sites on the fiber surface and hence the adsorption of polar dissolved compounds to the filter ( $R$. Simó pers. comm.). We cannot completely discard a certain adsorption of $\mathrm{DO}^{14} \mathrm{C}$ to the cellulose esters fibers of the CE0.22 filters used in our incubations. However, CE0.22 filters may be preferable to PC0.2 ones because of fast clogging and longer, sometimes unaffordable, filtering times with the latter type. The high vacuum pressures needed to avoid this problem would result in cell breakage and loss of $\mathrm{PO}^{14} \mathrm{C}$ (Venrick et al. 1987). A trade-off between time needed and accuracy must be achieved, taking into account that only particulate and dissolved primary production data obtained with the same filter type could safely be compared.

Acknowledgements. We thank the people on board RV 'Cornide de Saavedra' and RV 'Hespérides' for help and a good atmosphere. Determination of the phytoplankton composition in the Atlantic experiment was carried out by Pilar Pazos. We are also grateful to Enric Saiz for statistical advice and to Tarik Touahria for help during Expts 1 and 2. X.A.G.M. was a recipient of a FPI fellowship from the Spanish Ministry of Education and Culture. This work was supported by grants CICYT AMB94-0853, MAS3-CT97-0154, MAS3-CT96-0051, MAR95-1901-C03-03 and ANT96-0866.

\section{LITERATURE CITED}

Agustí S, Satta MP, Mura MP, Benavent E (1998) Dissolved esterase activity as a tracer of phytoplankton lysis: evidence of high phytoplankton lysis rates in the northwestern Mediterranean. Limnol Oceanogr 43:1836-1849

Baines SB, Pace ML (1991) The production of dissolved organic matter by phytoplankton and its importance to bacteria: patterns across marine and freshwater systems. Limnol Oceanogr 36:1078-1090

Biddanda B, Benner R (1997) Carbon, nitogen, and carbohydrate fluxes during the production of particulate and dissolved organic matter by marine phytoplankton. Limnol Oceanogr 42:506-518

Bird DF, Kalff J (1993) Protozoan grazing and size-activity structure in limnetic bacterial communities. Can J Fish Aquat Sci 50:370-380

Brock TD (1983) Membrane filtration: a user's guide and reference manual. Science Technology, Madison, WI

Chavez FP, Buck KR, Bidigare RR, Karl DM, Hebel D, Latasa $M$ Campbell L (1995) On the chlorophyll a retention properties of glass-fiber GF/F filters. Limnol Oceanogr 40 : $428-433$

Gächter R, Mares A, Tilzer MM (1984) Determination of phytoplankton production by the radiocarbon method: a comparison between the acidification and bubbling method (ABM) and the filtration technique. J Plankton Res 6:359-364

Gasol JM, Morán XAG (1999) Effects of filtration on bacterial activity and picoplankton community structure as assessed by flow cytometry. Aquat Microb Ecol 16: $251-264$

Gasol JM, del Giorgio PA, Massana R. Duarte CM (1995) Active versus inactive bacteria: size-dependence in a coastal marine plankton community. Mar Ecol Prog Ser 1.28:91-97 
Goldman JC, Dennet MR (1985) Susceptibility of some marine phytoplankton species to cell breakage during filtration and post-filtration rinsing. J Exp Mar Biol Ecol 86:47-58

Grande KD, Williams PJleB, Marra J, Purdie DA, Heinemann K, Eppley RW, Bender ML (1989) Primary production in the North Pacific gyre: a comparison of rates determined by the ${ }^{14} \mathrm{C}, \mathrm{O}_{2}$ concentration and ${ }^{18} \mathrm{O}$ methods. Deep-Sea Res 36:1621-1634

Hama T, Miyasaki T, Ogawa Y, Iwakuma T, Takahashi $M$, Otsuki A, Ichimura $S$ (1983) Measurement of photosynthethic production of a marine phytoplankton population using a ${ }^{13} \mathrm{C}$ stable isotope. Mar Biol 73:31-36

Hilmer T, Bate GC (1989) Filter types, filtration and postfiltration treatment in phytoplankton production studies. J Plankton Res 11:49-63

Jayakumar A, Barnes EMJr (1983) A filtration method for measuring cellular uptake of $\left[{ }^{14} \mathrm{C}\right]$ methylamine and other highly permeant solutes. Anal Biochern 135:475-478

Joint I, Pomroy A, Savidge G, Boyd P (1993) Size-fractionated primary productivity in the northeast Atlantic in May-July 1989. Deep-Sea Res II 40:423-440

Karl DM, Hebel DV, Björkman K, Letelier RM (1998) The role of dissolved organic matter release in the productivity of the oligotrophic North Pacific Ocean. Limnol Oceanogr 43:1270-1286

Lee S, Kang Y-C, Fuhrman JA (1995) Imperfect retention of natural bacterioplankton cells by glass fiber filters. Mar Ecol Prog Ser 119:285-290

Lewis MR, Smith JC (1983) A small volume, short-incubationtime method for measurement of photosynthesis as a function of incident irradiance. Mar Ecol Prog Ser 13:99-102

Li WKW (1990) Particles in 'particle-free' seawater: growth of ultraphytoplankton and implications for dilution experiments. Can J Fish Aquat Sci 47:1258-1268

Li WKW (1997) Cytometric diversity in marine ultraphytoplankton. Limnol Oceanogr 42:874-880

Li WKW, Dickie PM (1985) Growth of bacteria in seawater filtered through $0.2 \mu \mathrm{m}$ Nuclepore membranes: implications for dilution experiments. Mar Ecol Prog Ser 26:245-252

Lignell R (1990) Excretion of organic carbon by phytoplankton: its relation to algal biomass, primary productivity and bacterial secondary productivity in the Baltic Sea. Mar Ecol Prog Ser 68:85-99

Lignell R (1992) Problems in filtration fractionation of ${ }^{14} \mathrm{C}$ primary productivity samples. Limnol Oceanogr 37:172-178

Lindqvist K, Lignell $\mathrm{R}$ (1997) Intracellular partitioning of ${ }^{14} \mathrm{CO}_{2}$ in phytoplankton during a growth season in the northern Baltic. Mar Ecol Prog Ser 152:41-50

Mague TH, Friberg E, Hughes DJ, Morris I (1980) Extracellular release of carbon by marine phytoplankton; a physiological approach. Limnol Oceanogr 25:262-279

Maske H, Garcia-Mendoza E (1994) Adsorption of dissolved organic matter to the inorganic filter substrate and its implications for ${ }^{14} \mathrm{C}$ uptake measurements. Appl Environ Microbiol 60:3887-3889

Maurin N, Amblard C, Bourdier G (1997) Phytoplanktonic excretion and bacterial reassimilation in an oligomesotrophic lake: molecular weight fractionation. J Plankton Res 19:1045-1068

Milligan AJ, Cosper EM (1997) Growth and photosynthesis of the 'brown tide' microalga Aureococcus anophagefferens in subsaturating constant and fluctuating irradiance. Mar Ecol Prog Ser 153:67-75

Myklestad S (1977) Production of carbohydrates by marine planktonic diatoms. II. Influence of the N/P ratio in the growth medium on the assimilation ratio, growth rate, and production of cellular and extracellular carbohydrates by Chaetoceros affinis var. willei (Gran) Hustedt and Skeletonema costatum (Grev.) Cleve. J Exp Mar Biol Ecol 29 : 161 179

Nagata $T$ (1986) Carbon and nitrogen content of natural planktonic bacteria. Appl Environ Microbiol 52:28-32

Nalewajko C, Lean DRS (1972) Retention of dissolved compounds by membrane filters as an error in the ${ }^{14} \mathrm{C}$ method of primary production measurement. J Phycol 8:37-43

Parsons TR, Maita Y, Lalli CM (1984) A manual of chemical and biological methods for seawater analysis. Pergamon Press, Oxford

Riemann B, Jensen LM (1991) Measurements of phytoplankton primary production by means of the acidification and bubbling method. J Plankton Res 13:853-862

Schindler DW, Schmidt RV, Reid RA (1972) Acidification and bubbling as an alternative to filtration in determining phytoplankton production by the ${ }^{14} \mathrm{C}$ method. J Fish Res Board Can 29:1627-1631

Sciandra A, Gostan J, Collos Y, Descolas-Gros C, Leboulanger C, Martin-Jézéquel V, Denis $M$, Lefèvre D, CopinMontégut C, Avril B (1997) Growth-compensating phenomena in continuous cultures of Dunaliella tertiolecta limited simultaneously by light and nitrate. Limnol Oceanogr 42:1325-1339

Sheldon RW (1972) Size separation of marine seston by membrane and glass-fiber filters. Limnol Oceanogr 17:494-498

Smith DF (1974) Quantitative analysis of the functional relationships existing between ecosystem components. I. Analysis of linear intercomponent mass transfers. Oecologia 16:97-106

Steeman-Nielsen E (1952) The use of radioactive carbon $\left({ }^{14} \mathrm{C}\right)$ for measuring organic production in the sea. $J$ Cons Int Explor Mer 18:117-140

Stockner JG, Klut ME, Cochlan WP (1990) Leaky filters: a warning to aquatic ecologists. Can J Fish Aquat Sci 47 : $16-23$

Taguchi S, Laws EA (1988) On the microparticles which pass through glass fiber filter type GF/F in coastal and open waters. J Plankton Res 10:999-1008

Utermöhl H (1958) Zur Vervollkommung der quantitativen Phytoplankton-Methodik. Mitt Int Verein Theor Angew Limnol 9:1-38

Venrick EL, Cummings SL, Kemper CA (1987) Picoplankton and the resulting bias in chlorophyll retained by traditional glass-fiber filters. Deep-Sea Res 34:1951-1956

Williams PJleB, Jenkinson NW (1982) A transportable microprocessor-controlled precise Winkler titration suitable for field station and shipboard use. Limnol Oceanogr 27 : $576-584$

Witek Z, Ochocki S, Maciejowska M, Pastuszak M, Nakonieczny J, Podgórska $B$, Kownacka JM, Mackiewicz $T$, Wrzesinska-Kwiecien $M$ (1997) Phytoplankton primary production and its utilization by the pelagic community in the coastal zone of the Gulf of Gdansk (southern Baltic). Mar Ecol Prog Ser 148:169-186

Yentsch CS (1983) A note on the fluorescence characteristics of particles that pass through glass-fiber filters. Limnol Oceanogr 28:597-599

Yentsch CS, Menzel DW (1963) A method for the determination of phytoplankton chlorophyll and phaeophytin by fluorescence. Deep-Sea Res 10:221-231

Submitted: March 9, 1999; Accepted: May 20, 1999

Proofs received from author(s): October 1, 1999 